\title{
MONITORING OF SOME CHANGES IN MANZALA LAKE USING REMOTE SENSING AND GIS TECHNIQUES
}

\author{
MOHAMED. M. SHOMAN
}

RS \& GIS Unit, Soils, Water and Environment Research Institute, ARC.

(Manuscript received 2 October 2018)

\begin{abstract}
M anzala Lake is one of the largest lakes in the north of the Nile Delta of Egypt and it is the most important source of fish production. The lake is exposed to many impacts by human activities, such as drying some parts of the lake to be used as agricultural and urban areas as well as the deduction of large parts of the lake for fishponds establishment. This study aims at monitoring the changes occurred to the lake at different time intervals using the analyses of multi temporal satellite images of sensors LANDSAT-1 MSS, LANDSAT-5 TM, SPOT-4, and Sentinel-2A for years 1972, 1984, 1991, 2006 and 2017. Normalized Difference Water Index (NDWI), Modified Normalized Difference Water Index (MNDWI) and supervised maximum likelihood classification were used. Results showed that Manzala Lake area decreased by more than $60 \%$ during the study period from 1972 to 2017. Derived areas of Manzala Lake at the studied periods from 1972 to 2017 were classified according to land cover classes using supervised classification approach to 4 main classes: cultivated areas (about 75051 fed), bare areas (about 65673 fed), urban areas (about 1338 fed), and fishponds (about 83721 fed). Comparing the results of the lost areas of the lake through the period 1972-2017 with the total area of land cover classes derived from the lake in the same period, it is found that a difference between the two areas is about $629 \mathrm{fed}$. $(0.2 \%$ of the total area of Manzala Lake in 1972) it can be considered that these soils were eroded and lost from the lake by the Mediterranean Sea effect.
\end{abstract}

\section{INTRODUCTION}

Along the northern coast of the Nile Delta extends a chain of lakes (Manzala, Burullus, Idku, and Maryut). All of the lakes excluding Maryut are joined to the Mediterranean directly. Most of them have an elongated shape aligned with the direction of the coast (Dinar et al., 1995).

Manazla Lake is the largest lake, which located in the northeastern quadrant of the Nile Delta. It lies between the Mediterranean, the Suez Canal, and the Damietta branch. The lake is $47 \mathrm{~km}$ long from northwest to southeast, and $30 \mathrm{~km}$ wide, and it narrows in the middle to only $17 \mathrm{~km}$. There is a large number of islands in the lake (1022), cover 31.370 feddans and representing $9 \%$ of the area of the lake. Some islands extend from northeast to southwest and formed of clay; i.e. Kum Al-Dahab Island and Ibn Salam Island. Other islands extend from northwest to southeast; these islands described as bars of sand. Such as Tanis, Al-Battikh, Diyab, and Hatab Islands. Halophytic grasses grow on the shores of these islands, but their interiors are barren. Along the southern shore of the lake are a number of bays and lakes. Some of them 
are joined to the lake, either directly or by narrow straits. Around the lake, mainly in the east and southeast. Ashtum Al-Gamil is the main Strait, which joined Manazla Lake with the Mediterranean Sea. In addition, many other openings which the lake reaches the sea. there are many inlets in the southern coast of Manzala Lake which great amounts of water drain into the lake such as El-Sherw, El-Gammaliah, Hadous, Ramsis, and Bahr El-Baqar drains and others (Elmorsi et al., 2017).

The area of Manzala Lake was reduced about $50 \%$ during the beginnings of 1990,s (Abdel-Baky and El-Ghobashy, 1990) due to agricultural reclamation activities. Manzala Lake economically is considered one of the most important lakes in the North Delta in Egypt for fishing activity, where, the lake was supplied the Egyptian people with approximately $50 \%$ of the total Egyptian fish catch (Bishai and Yosef, 1977). It is contribution was reduced to $30 \%$ of the total Egyptian fish catch (Abdel Ghaffer, 2006). Moreover, in the north of the lake, there is Ashtoum El Gamil area which consider a protected area, where it is completely located inside the lake and have an area about $175 \mathrm{~km}^{2}$. This area was created to protect many migratory and resident species of birds, fish, natural plants and some historical sites scattered throughout the lake. Therefore, there is a proposal to extend this protected area to include more important parts of Manzala Lake (Dewidar, 2011).

a study explained that the Manzala Lake decreased about $50 \%$ from period 1973 until 2003 which is the main reason for ecosystem degradation processes of the lake was due to human activity such as drying and reclaiming process, establish development projects and urban settlements (Ahmed, et al., 2006).

Using of remote sensing has several advantages, including detecting of earth resources. Generally, change detection involves the application of multi-temporal database to quantitatively analyze the temporal change of the surface features. (Lu et al., 2004).

Changes in land use/land cover have been identified as key themes for monitoring environmental change and natural resource management through planning and mapping of land use/land cover types to support the sustainable management of natural resources (Lambin et al., 2003).

The objectives of this study aim at monitoring the changes in the water body of Manzala Lake and effect of that on some ecological changes such as the changes in land cover of derived areas of Manzala Lake from 1972 to 2017 using NDWI and MNDWI models with different satellite images sensors. 


\section{MATERIALS AND METHODS}

\section{Study area:}

Manzala Lake is located on the northeastern edge of the Nile Delta within four governorates named; Al-Dakahlia, Damietta, Al-Sharkia and Port Said, and separated from the Mediterranean Sea by a sandy beach bridge. It is located between latitudes $31^{\circ} 07^{`} \mathrm{~N}$ and $31^{\circ} 30^{\circ} \mathrm{N}$ and longitudes $31^{\circ} 48^{\circ} \mathrm{E}$ and $32^{\circ} 17^{`} \mathrm{E}$ (Figure 1).

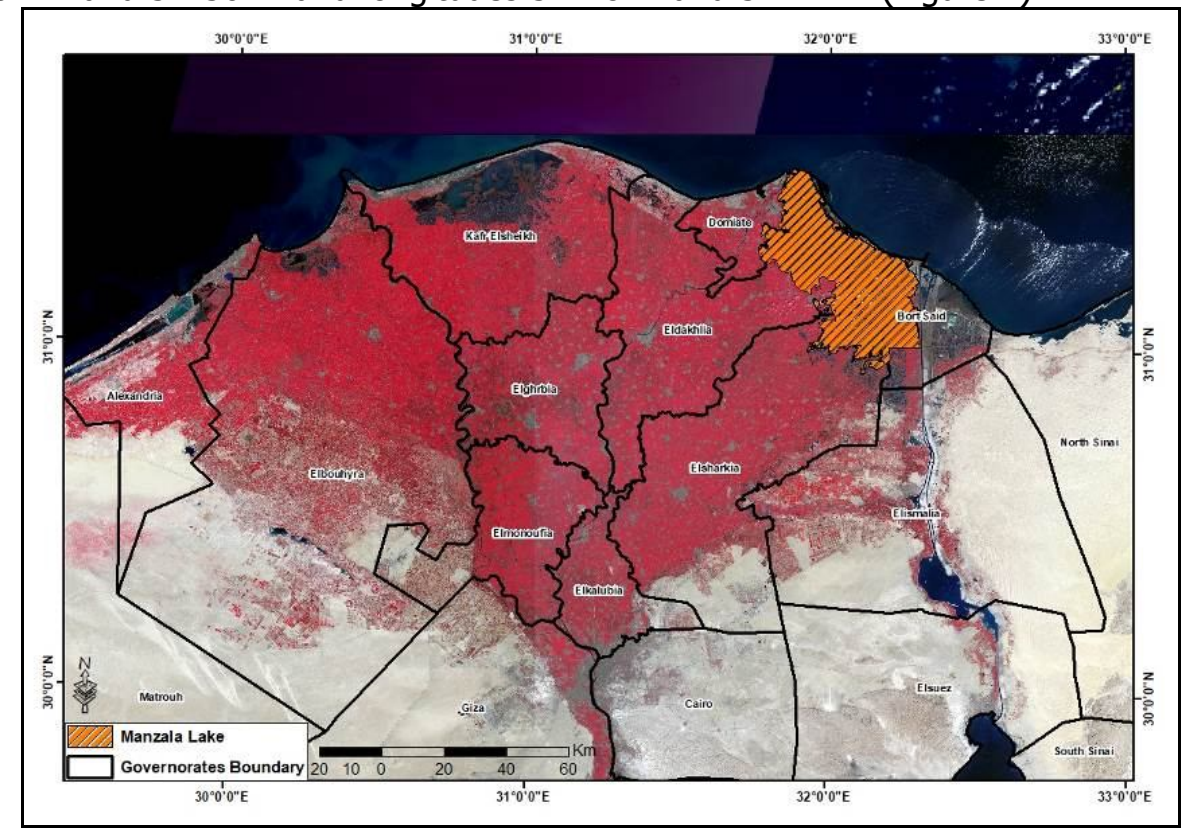

Figure 1. Location of the study area.

\section{Materials:}

\subsection{Remote sensing data:}

Five Multi temporal of available satellite images (For years 1972, 1984, 1991, 2006 and 2017) were used to determine the lake areas and detecting the land cover classes of the lost areas of Manzala Lake (Figure 2). The satellites used in this study are: Landsat-1 MSS, which was launched in 1972 and in 1978 the satellites was taken out of service, Landsat-5 TM which was launched in 1984 and in 2011 the satellite was decommissioned from the service, SPOT 4 (HRVIR) which was launched in 1998 and became out of the service in 2013 and Sentinel-2A sensor which was launched in 2015. Spectral resolution, acquired date and multispectral bands specification of the data used are shown in Table 1: 


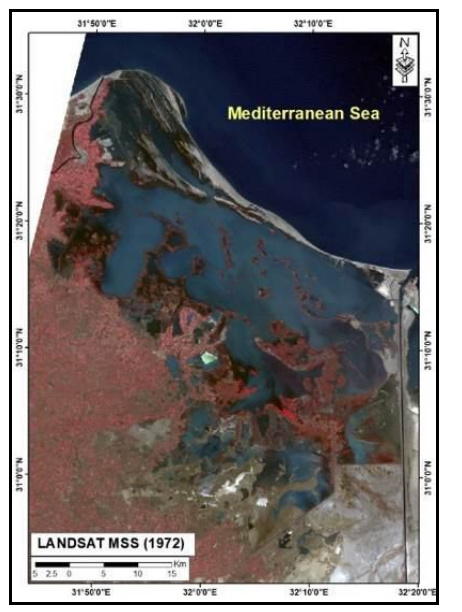

a) Landsat MSS (1972)

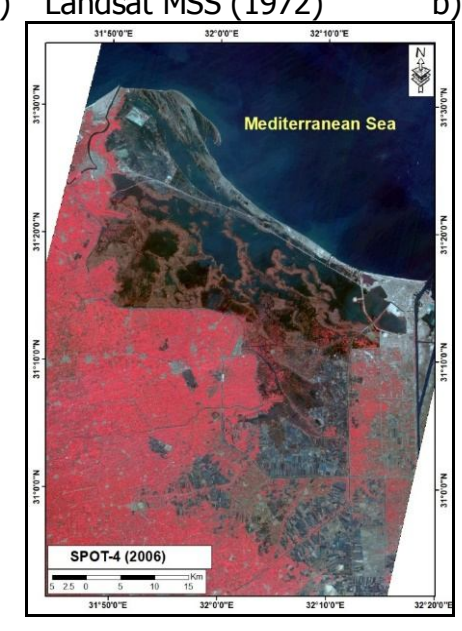

d) SPOT-4 (2006)

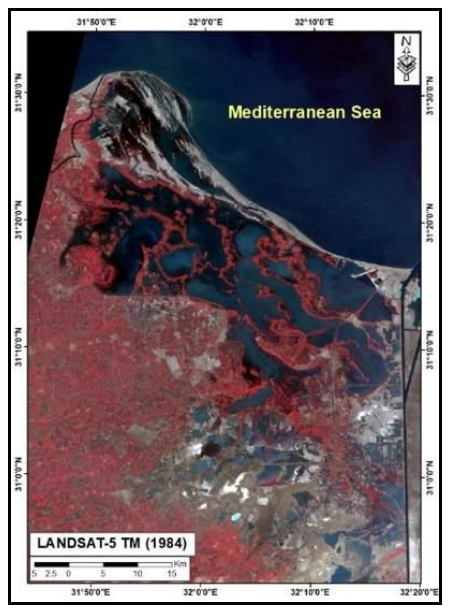

b) Landsat-5 TM (1984)

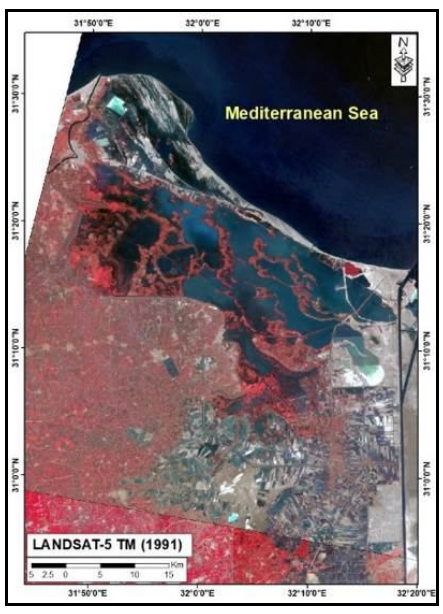

c) Landsat-5 TM (1991)

Figure 2. Multi-temporal of a) MSS, b \& c) TM, d) Spot and e)

Sentinel images of the study area.

Table 1. Spectral resolution, acquired date and multispectral bands specification of the used satellite data

\begin{tabular}{|c|c|c|c|c|c|}
\hline \multicolumn{2}{|c|}{ Satellite Data } & Landsat-1 MSS & Landsat-5 TM & SPOT 4 & Sentinel-2A \\
\hline \multicolumn{2}{|c|}{ Spatial Resolution } & $58 \mathrm{~m}$ & $28.5 \mathrm{~m}$ & $20 \mathrm{~m}$ & $10 \mathrm{~m}$ \\
\hline \multicolumn{2}{|c|}{ Acquired Date } & August 1972 & $\begin{array}{l}\text { July } 1984 \\
\text { June } 1991\end{array}$ & June 2006 & Jun 2017 \\
\hline \multirow{5}{*}{ 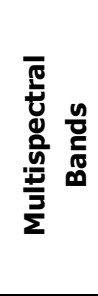 } & Blue band & & $0.45-0.52 \mu \mathrm{m}$ & & $0.490-0.560 \mu \mathrm{m}$ \\
\hline & Green band & $0.5-0.6 \mu \mathrm{m}$ & $0.52-0.60 \mu \mathrm{m}$ & $0.5-0.59 \mu \mathrm{m}$ & $0.560-0.665 \mu \mathrm{m}$ \\
\hline & Red band & $0.6-0.7 \mu \mathrm{m}$ & $0.63-0.69 \mu \mathrm{m}$ & $0.61-0.68 \mu \mathrm{m}$ & $0.665-0.705 \mu \mathrm{m}$ \\
\hline & $\begin{array}{l}\text { Near infrared } \\
\text { (NIR) band }\end{array}$ & $\begin{array}{l}0.7-0.8 \mu \mathrm{m} \\
0.8-1.1 \mu \mathrm{m} \\
\end{array}$ & $0.76-0.90 \mu \mathrm{m}$ & $0.79-0.89 \mu \mathrm{m}$ & $0.842-0.865 \mu \mathrm{m}$ \\
\hline & $\begin{array}{l}\text { Mid-infrared } \\
\text { (MIR) Band }\end{array}$ & & $\begin{array}{l}1.55-1.75 \mu \mathrm{m} \\
2.08-2.35 \mu \mathrm{m}\end{array}$ & $1.58-1.75 \mathrm{~mm}$ & \\
\hline
\end{tabular}

\subsection{Topographic maps}

Twelve topographic maps with a scale of $1: 50,000$ produced by the Egyptian General Survey Authority (EGSA, 1988) covering the study area, were used to georeference the satellite data. The names of these maps (EGSA, 1988) are: Port 
Said, Bar Al-Dahrah, Damietta, Faraskur, Port Foad, Al-Matariya, Al-Manzala, AlQantarah, Bahr El-Baqar drain, San Al-Hagar, Ismalia, and Abu-Soiear.

\subsection{Remote sensing and GIS softwares:}

- ERDAS IMAGINE 2014 software (ERDAS, 2014) for geospatial applications with IMAGINE objective feature extraction module.

- ArcGIS V. 10.4.1 software (ESRI, 2016).

\section{Methods:}

\subsection{Image Processing}

- Geometry Correction: Geometric correction process depends on using ground control points (GCPs) which collected from topographic maps done to register the satellite images. The satellite images were originally Georeferenced to the Universal Transverse Mercator (UTM) projection. In addition, Due to the difference of spatial resolution for used images, rescale processes were used to resampling the pixel size of sentinel-2A image to $20 \mathrm{~m}$.

- Normalized and Modified Normalized Difference Water Index (NDWI\& MNDWI): Two models (NDWI and MNDWI) were used to determine the lake areas. The Normalized Difference Water Index (NDWI) was proposed to detect and measure the surface waters in wetland environments (McFeeters, 1996), and to produce a single grayscale images, where water surface is bright. The NDWI is calculated using the following Equation:

$$
\text { NDWI }=\frac{\rho \text { Green }-\rho \text { NIR }}{\rho \text { Green }+\rho \text { NIR }}
$$

Where $\rho$ the reflectance value of the green and near infrared (NIR) bands. Values of NDWI greater than zero represent water surfaces, while values less than, or equal, to zero represent non-water surfaces. The modified normalized difference water index (MNDWI) $(X u, 2006)$ is generated to use with satellite date have middle infrared (MIR) band such as data of Landsat TM and Spot-4 and calculated using the following Equation:

$$
\text { MNDWI }=\frac{\rho \text { Green }-\rho \text { MIR }}{\rho \text { Green }+\rho \text { MIR }}
$$

Where $\rho$ the reflectance value of the middle infrared (MIR) band.

- Classification and change detection algorithm of lost areas: Supervised Maximum Likelihood classification is a method in which the analyst defines small areas called training sites on the image, which representative samples for each land cover class. The software then uses these "training sites" and applies them to the entire image. (Černa and Chytry, 2005). 


\section{RESULTS AND DISCUSSIONS}

\subsection{Changes of water bodies of Manzala Lake from 1972 to 2017:}

Using the modeler function in ERDAS Imagine Software, the two indices, NDWI and MNDWI were generated and tested for the all available data. NDWI and MNDWI were used to detect the surface of water within Manzala Lake, while both the floating vegetation and the islands were located within the lake using the image classification. The results of applying of the two models, illustrated that the NDWI was utilized to LANDSAT MSS image of 1972 and Sentina-2A image of 2017 (Figure 3). The MNDWI was utilized to LANDSAT-5 TM images of 1984 and 1991 and SPOT-4 image of 2006 (Figure 4) because of presence of MIR band in this data and non-presence in LANDSAT MSS and Sentinel-2A data.

The analysis has identified the rate of environmental changes over 45 years for Manzala Lake; this was undertaken using satellite images to employ historical remotely sensed data to reveal the long-term changes in the lake as shown in Table 2.

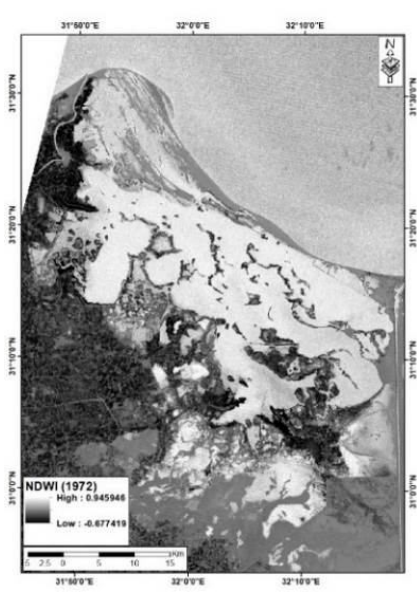

NDWI of Landsat MSS 1972

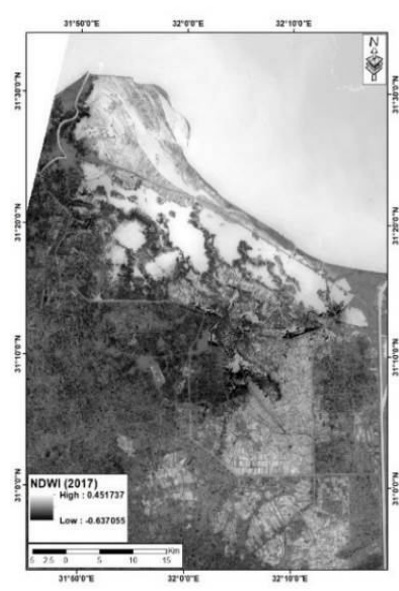

NDWI of Sentinel-2A 2017

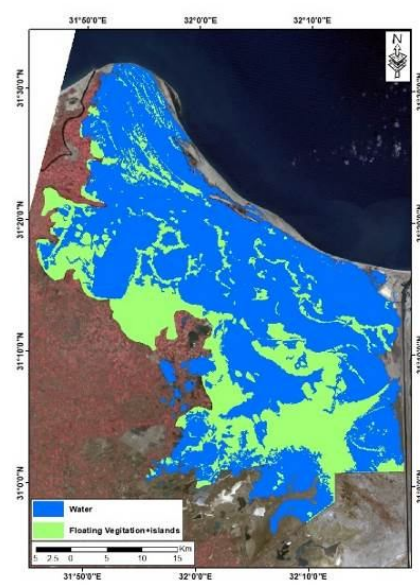

NDWI 1972+Floating Vegetation + islands

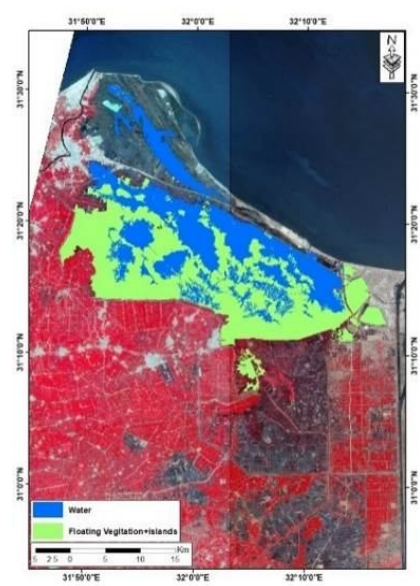

NDWI 2017+Floating Vegetation + islands

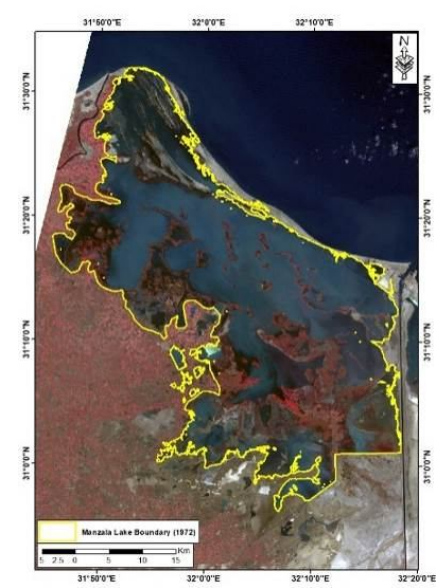

Manzala Lake Boundary 1972

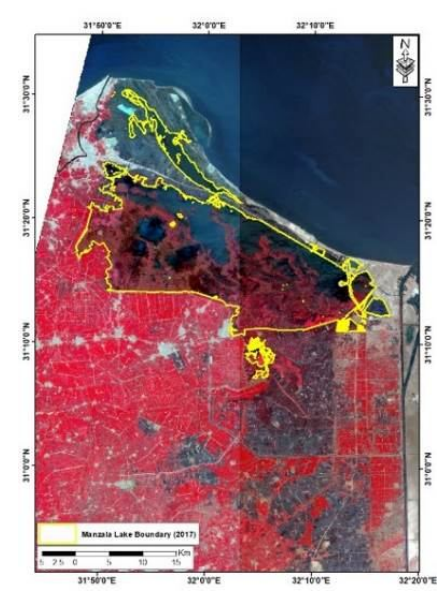

Manzala Lake Boundary 2017

Figure 3. Manzala Lake boundaries in Years 1972, and 2017 using NDWI Models 


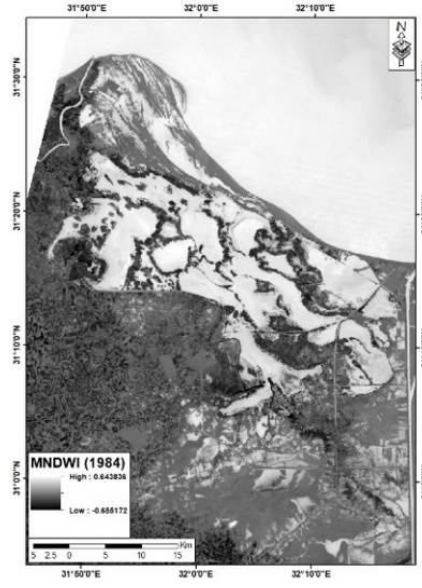

MNDWI of Landsat-5 TM 1984

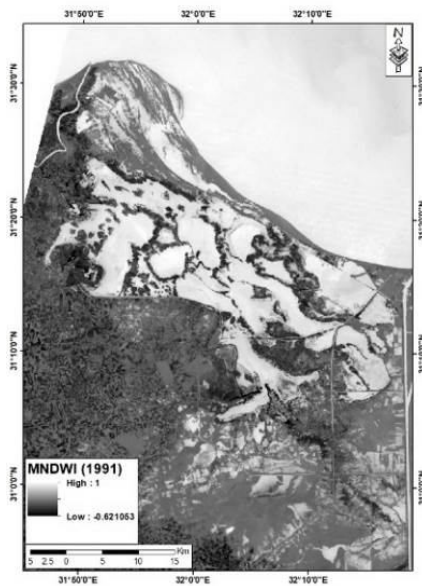

MNDWI of Landsat-5 TM 1991

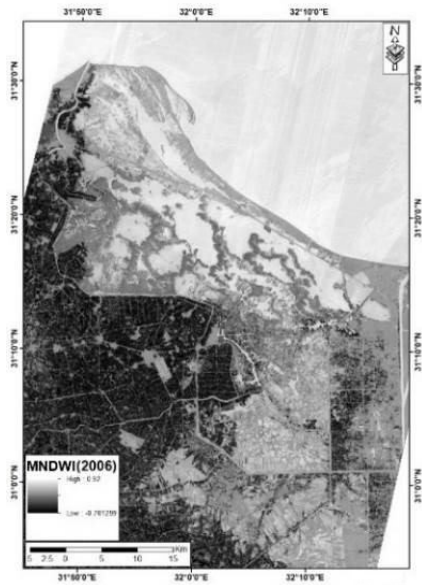

MNDWI of SPOT-4 2006

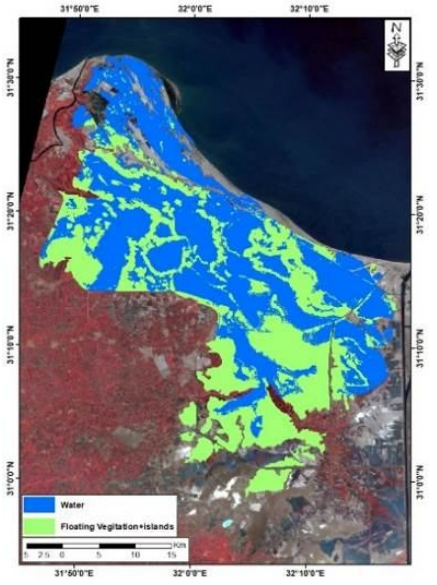

NDWI 1984+Floating Vegetation + islands

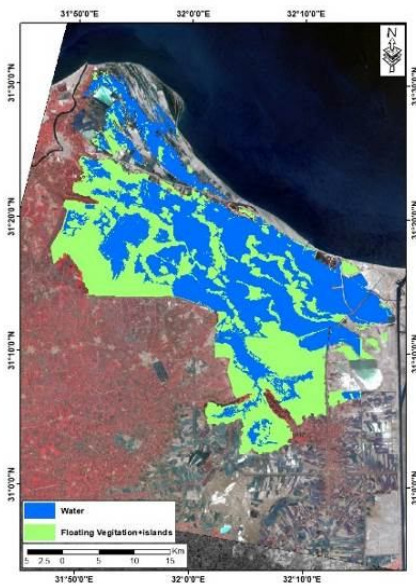

NDWI 1991+Floating Vegetation + islands

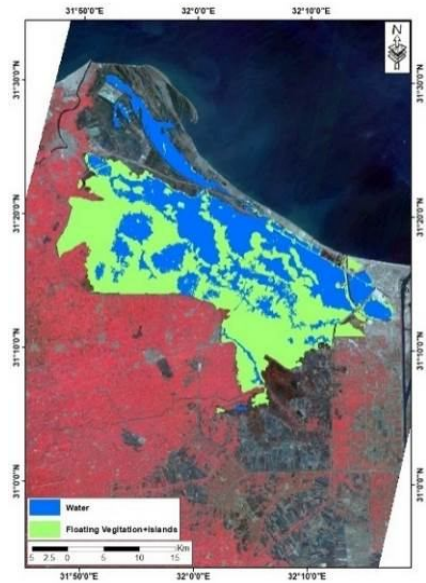

NDWI 2006+Floating Vegetation + islands

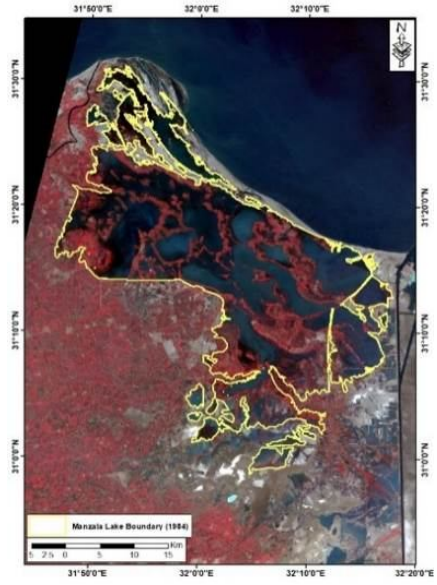

Manzala Lake Boundary 1984

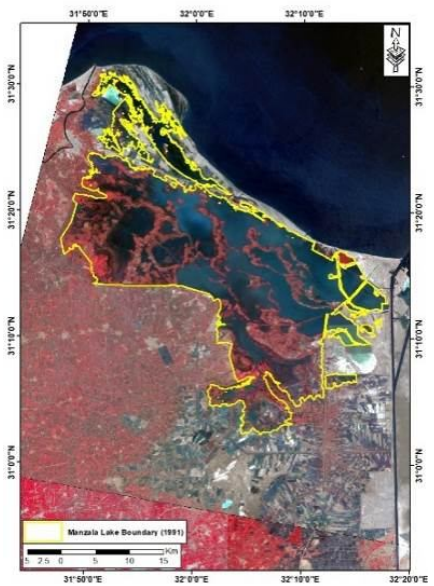

Manzala LakeBoundary 1991

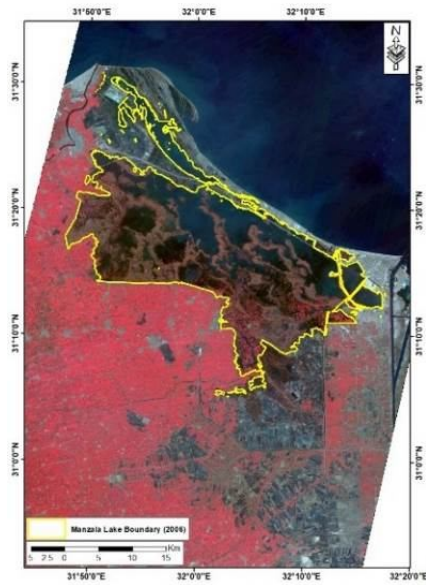

Manzala Lake Boundary 2006

Figure 4. Manzala Lake boundaries in Years 1984, 1991 and 2006 using MNDWI Models 
Table 2. Manzala Lake areas in years 1972, 1984, 1991, 2006 and 2017

\begin{tabular}{|c|c|c|c|c|c|c|c|}
\hline \multirow[b]{2}{*}{ Year } & \multicolumn{3}{|c|}{ Manzala Lake Area } & \multirow{2}{*}{$\begin{array}{l}\text { Periods } \\
\text { (Year) }\end{array}$} & \multicolumn{3}{|c|}{ Change in Area } \\
\hline & Fed. & $\mathbf{K m}^{2}$ & $\begin{array}{c}\% \\
\text { (Area } \\
1972 \text { ) }\end{array}$ & & Fed. & $\mathbf{K m}^{2}$ & $\%$ \\
\hline 1972 & 372970 & 1566 & 100 & & - & - & - \\
\hline 1984 & 257092 & 1080 & 68.9 & 12 & 115878 & 487 & 31.1 \\
\hline 1991 & 215261 & 904 & 57.7 & 7 & 41831 & 176 & 16.3 \\
\hline 2006 & 168433 & 707 & 45.2 & 15 & 46828 & 197 & 21.8 \\
\hline 2017 & 146558 & 616 & 39.3 & 11 & 21875 & 92 & 13 \\
\hline \multicolumn{5}{|c|}{ Total Changed Area } & 226412 & 951 & \\
\hline
\end{tabular}

The area of Manzala Lake was 372970 fed. (1566 Km2) in 1972. The results revealed that Manzala Lake area lost about $31.1 \%$ (487 km2) from 1972 until 1984, $16.3 \%$ (176 km2) from 1984 until 1991, $21.8 \%$ (197 km2) from 1991 until 2006, and $13.0 \%$ (92 km2) from 2006 until 2017 (Table 2 and Figure 5). On general results illustrated that Manzala Lake area in 2017 (146558 fed.) represents about $39.3 \%$ of the lake area in 1972 , with a total loss about $60.7 \%$, the loss rate is about $4763 \mathrm{fed} / \mathrm{yr}$. according to applied the linear regression formula (Figure 6) as shown by the following equation:

$$
y=-4763 x+336850
$$

Where: $y$ Area of Manzala Lake (fed.) and $x$ is number of years.

This means that the Manzala Lake area has been heavily impacted by human activities such as drying and land filling processes of land reclamation, urban encroachment and establishing fishponds. Using this relationship, it is possible to predict the lake area after certain periods if the loss rate of the lake continues constant due to the continuous human activities. This leads to an expectation of disappearance of the lake in year 2042. 


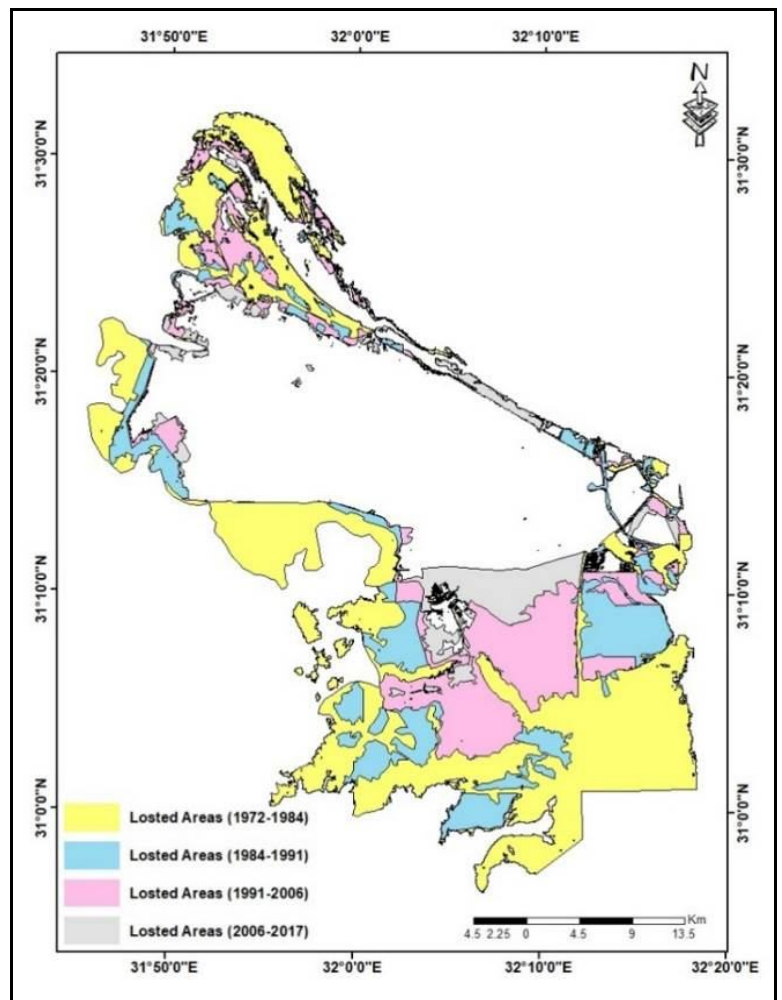

Figure 5. Lost areas map of Manzala Lake through the periods (1972-1984, 1984-1991, 1991-2006 and 2006-2017).

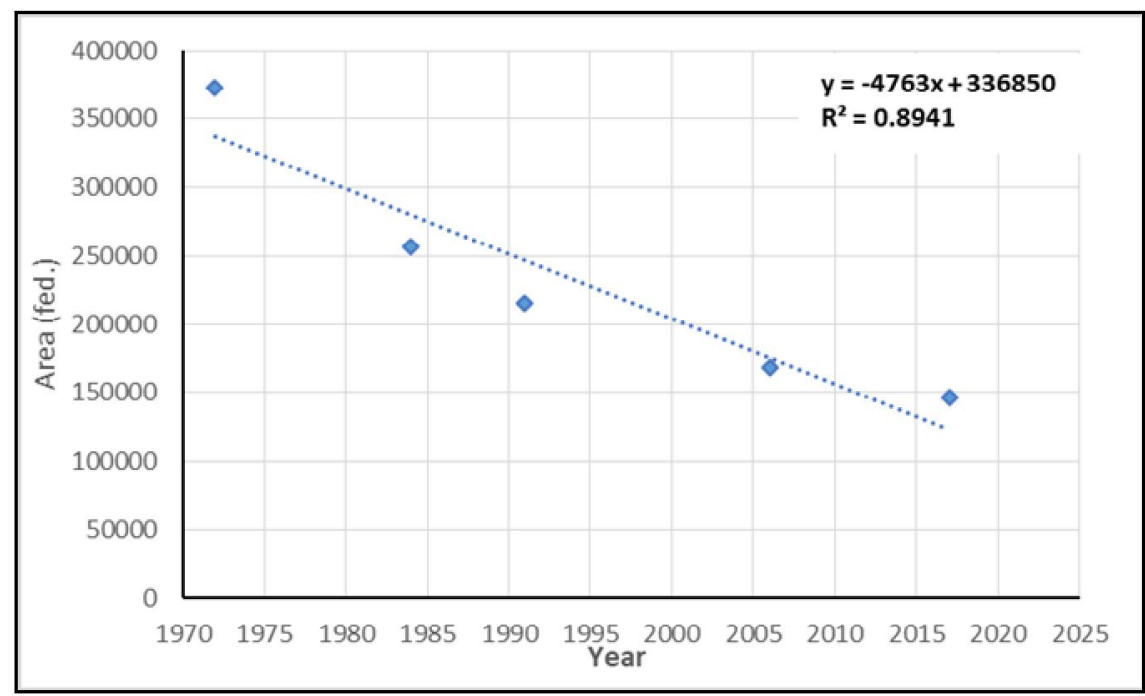

Figure 6. Rate of Manzala Lake area changes

\subsection{Classification for derived areas of Manzala Lake from 1972 to 2017:}

Supervised maximum likelihood classification was applied for images 1972, 1984, 1991, 2006 and 2017 to monitor the changes in land cover classes in the derived areas. Land cover areas were classified to 4 classes as shown in Figure 7 as follows:

a. Cultivated Areas: lands reclaimed and cultivated with crops. 
b. Bare Areas: lands which in early stage of reclamation, some dried areas behind the lakes used as platforms, sand beaches and salt evaporation basin.

c. Urban Areas: this class include residential (villages) and service areas.

d. Fishponds: which located around the lake and near on the Mediterranean Sea.
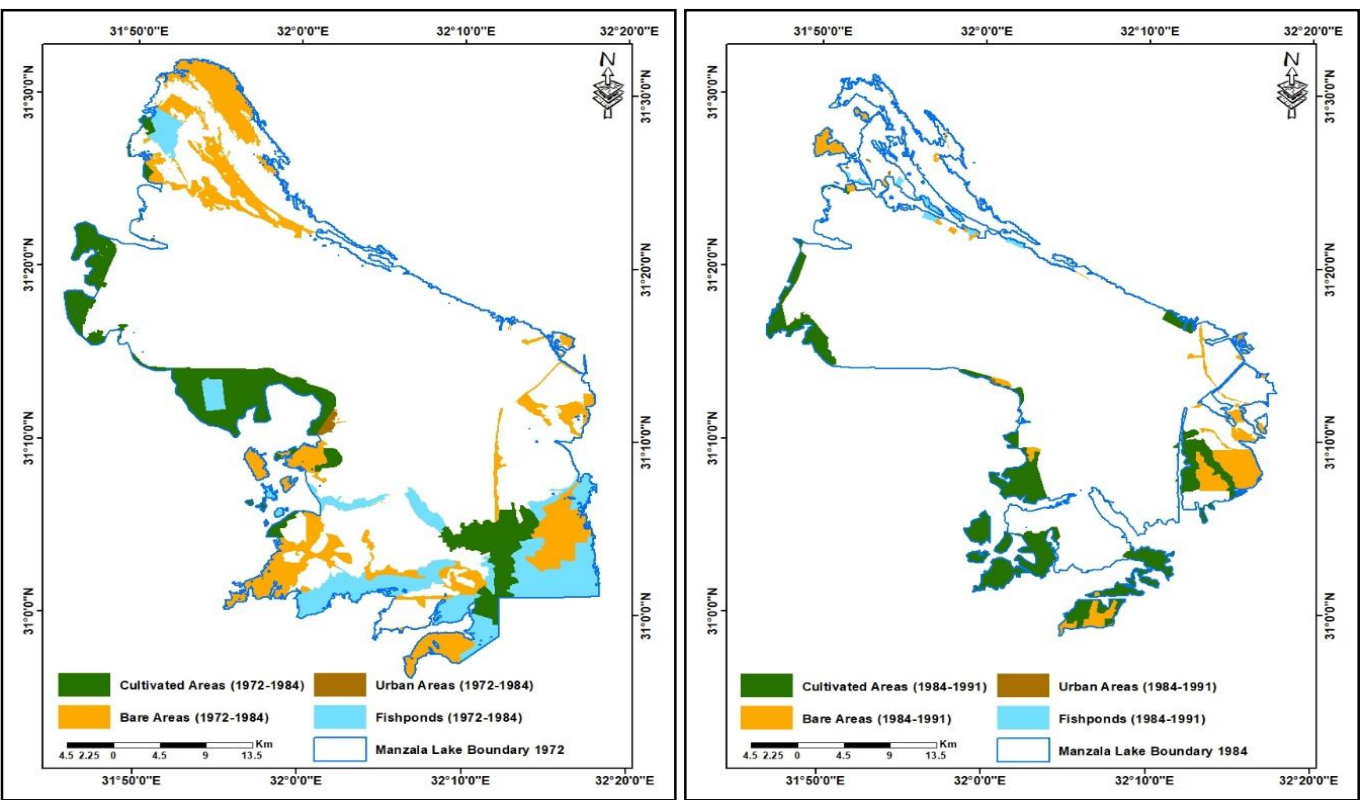

(a)

(b)

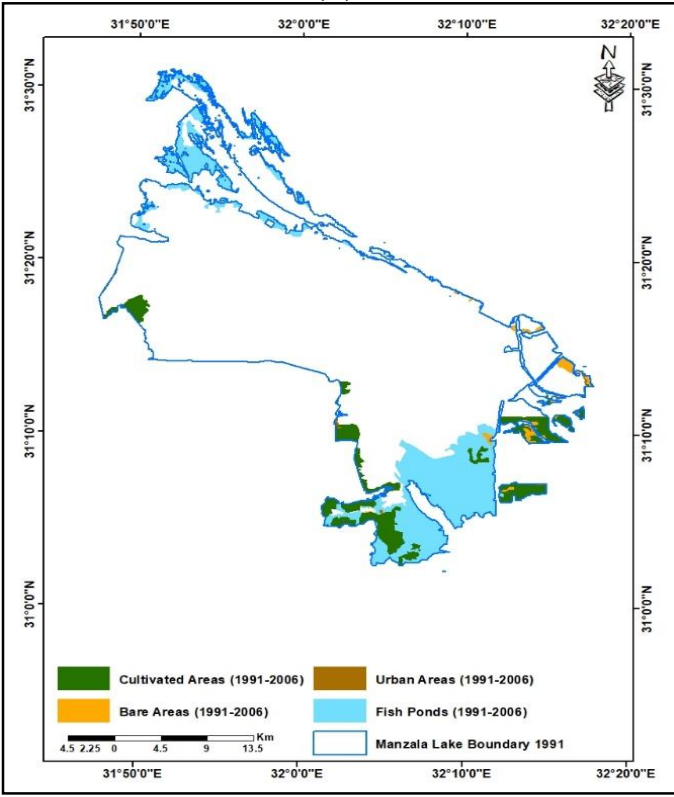

(c)

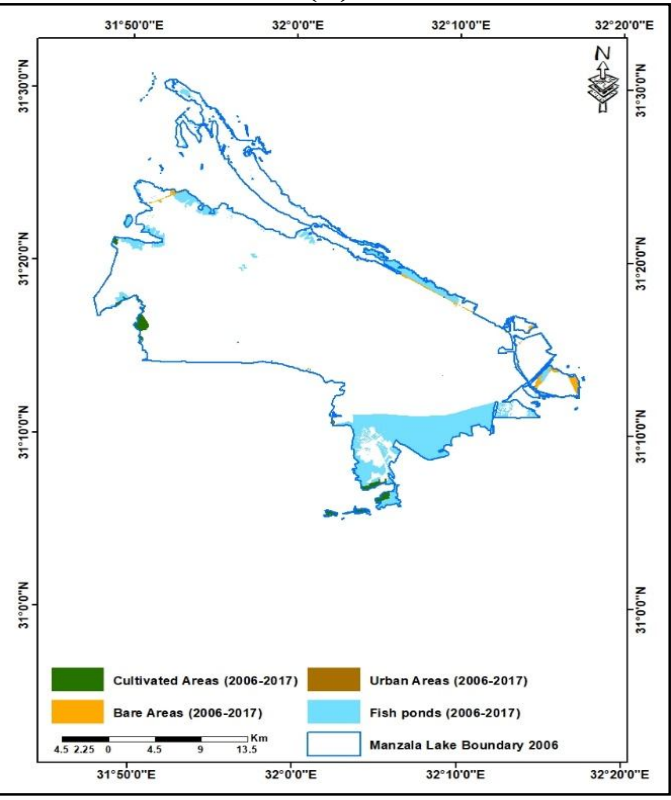

(d)

Figure 7. Land cover classification maps of the derived area

(a- 1972-1984, b- 1984-1991, c- 1991-2006 and d- 2006-2017)

Areas of each class were calculated in each time period and the results are shown in Table 3 and Figure 8 as follows: 
Table 3. Land cover classes of the lost areas of following periods from 1972 to 2017

\begin{tabular}{|c|c|c|c|c|c|c|c|c|c|c|}
\hline \multirow{2}{*}{$\begin{array}{c}\text { Land Cover } \\
\text { Class }\end{array}$} & \multicolumn{2}{|c|}{ 1972-1984 } & \multicolumn{2}{|c|}{ 1984-1991 } & \multicolumn{2}{|c|}{ 1991-2006 } & \multicolumn{2}{|c|}{ 2006-2017 } & \multicolumn{2}{|c|}{$\begin{array}{l}\text { Total Areas } \\
1972-2017\end{array}$} \\
\hline & $\begin{array}{l}\text { Area } \\
\text { (fed.) }\end{array}$ & $\begin{array}{c}\% \\
\text { (1972) }\end{array}$ & $\begin{array}{l}\text { Area } \\
\text { (fed.) }\end{array}$ & $\begin{array}{c}\% \\
\text { (1984) }\end{array}$ & $\begin{array}{l}\text { Area } \\
\text { (fed.) }\end{array}$ & $\begin{array}{c}\% \\
\text { (1991) }\end{array}$ & $\begin{array}{l}\text { Area } \\
\text { (fed.) }\end{array}$ & $\begin{array}{c}\% \\
(2006)\end{array}$ & $\begin{array}{c}\text { Area } \\
\text { (fed.) }\end{array}$ & $\begin{array}{c}\% \\
\text { (1972) }\end{array}$ \\
\hline Cultivated Areas & 33802 & 9.1 & 26865 & 10.4 & 12637 & 5.9 & 1747 & 1.0 & 75051 & 20.1 \\
\hline Bare Areas & 49653 & 13.3 & 12905 & 5.0 & 1883 & 0.9 & 1232 & 0.7 & 65673 & 17.6 \\
\hline Urban Areas & 695 & 0.2 & 195 & 0.1 & 302 & 0.1 & 146 & 0.1 & 1338 & 0.4 \\
\hline Fishponds & 31206 & 8.4 & 1565 & 0.6 & 32199 & 15.0 & 18751 & 11.1 & 83721 & 22.4 \\
\hline Total Area & 115356 & 30.9 & 41530 & 16.2 & 47021 & 21.8 & 21876 & 13.0 & 225783 & 60.5 \\
\hline
\end{tabular}

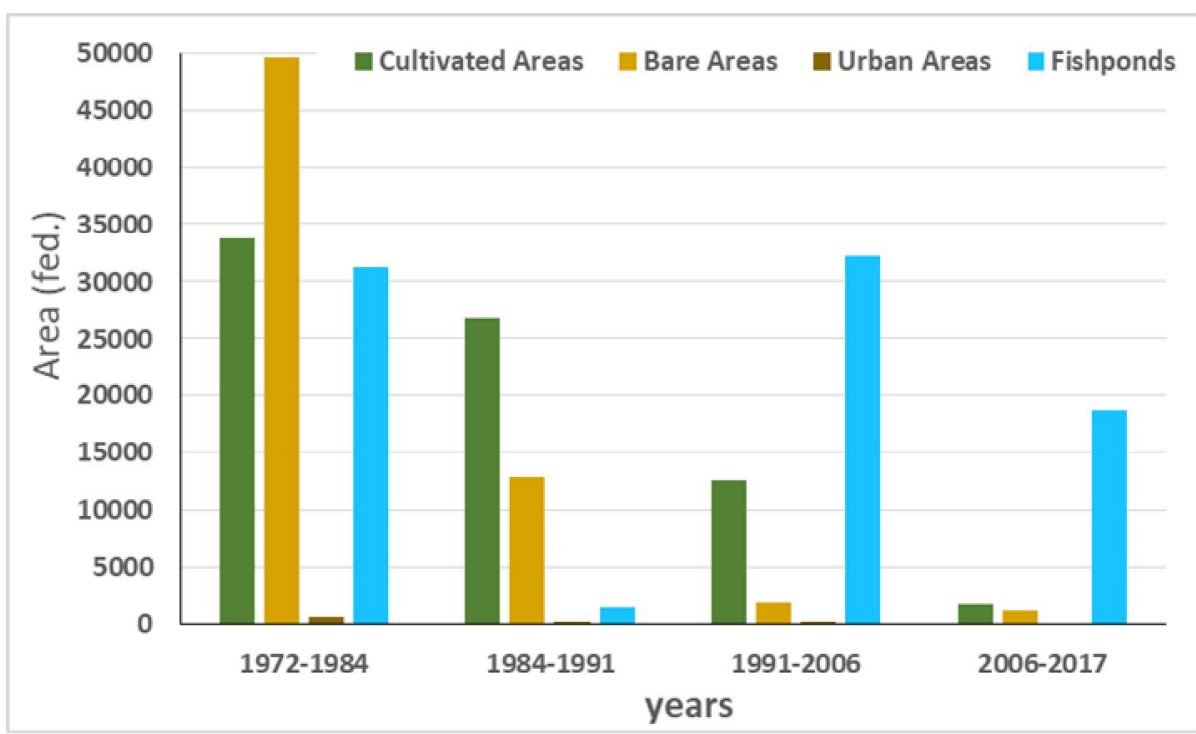

Figure 8. Land cover classes chart of the lost areas from Manzala Lake from 1972 to 2017

It is clear that during the period (1972-2017) about $60.5 \%$ of Manzala Lake area in 1972 were changed to other land cover features in 2017 as the result of human activities, such land reclamation, urban encroachment and fishponds establishment. Maximum rate of draying and land filling process for Manzala Lake recorded through the period from 1972-1984 (13.3\% of lake area 1972) as it is the first step of land reclamation process. During the period from 1984-1991, cultivated area recorded the maximum rate (10.4\% of lake area 1984). Fishponds establishment recorded maximum rate during the period from 1991-2006 (15\% of lake area 1991), while urban encroachment process recorded the maximum rate through the period 19721984 (0.2 \% of lake area 1972). Throughout the study period from 1972-2017, fishponds establishment was the biggest activity in the study area (22.4\%), followed by cultivation (20.1\%) and presence of bare areas and urban encroachment (17.6 \% and $0.4 \%$ respectively) as the result of drying and land filling process. Comparing the 
results of the lost areas of the lake through the period 1972-2017 (about 226412 fed.) with the total area of land cover classes derived from the lake in the same period (about 225783 fed.), it is found that a difference between the areas is about 629 fed. ( $0.2 \%$ of the total area of Manzala Lake in 1972). It can be considered that these areas were eroded and lost from the lake by the Mediterranean Sea effect as shows in Figure 9.

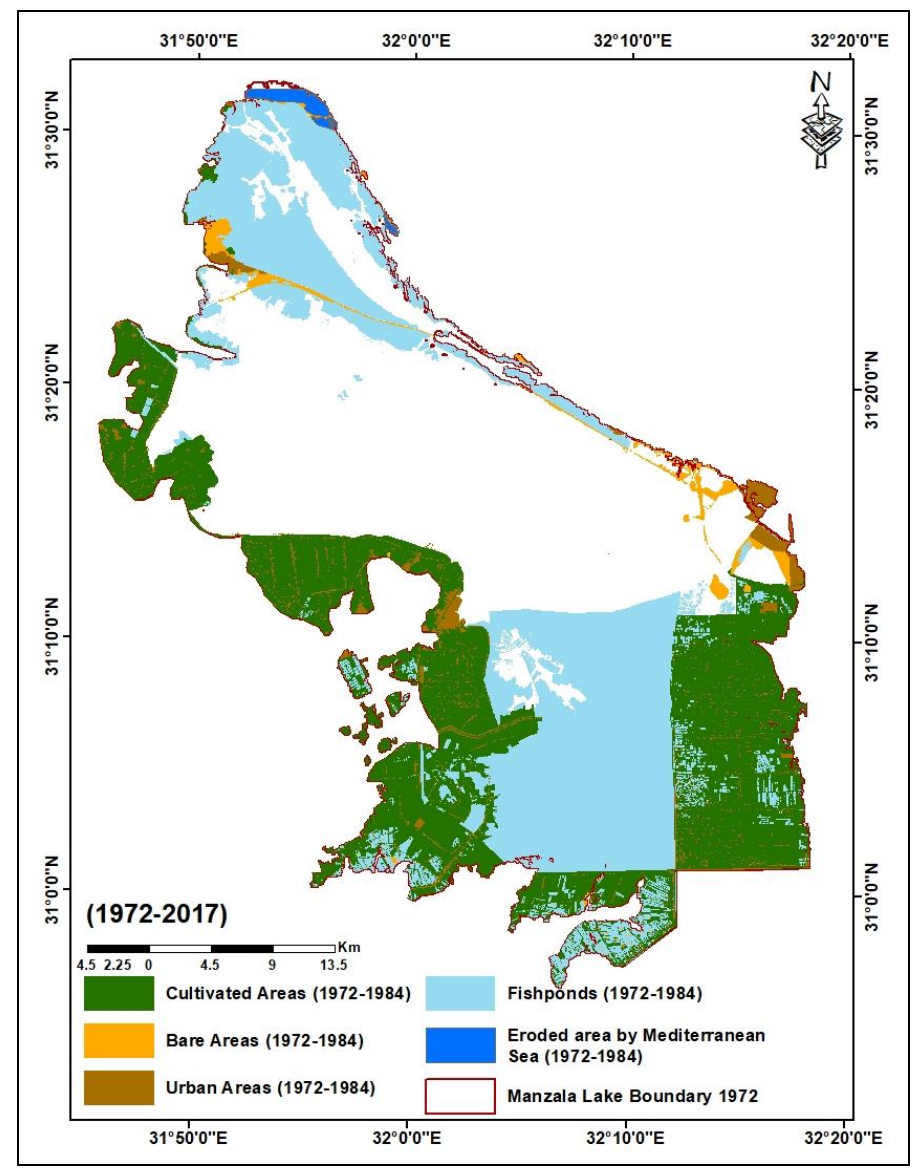

Figure 9. Land cover maps of derived areas of Manzala Lake since 1972 to 2017

\section{CONCLUSION}

Human activities are the main factors affected the Manzala Lake area. As a result of these activities, there has been a large loss of the surface area of the lake with continuous of these factors, this leads to a possibility of disappearance of the lake in the future, which may result in changes affecting the ecological balance of the study area. There are some models can help researchers to use the latest technologies such as remote sensing, GIS techniques and multi-temporal satellite images in studying such phenomena in an easy and fast way.

Therefore, by these studies, governments could take the necessary measures to reduce the aggression on the lakes by enacting laws governing the use of the lake to prevent the over-drying of lake water and minimize all factors and causes that eventually lead to a decrease in the lake area. 


\section{REFERENCES}

1. Abdel-Baky, T. E. and A. E. EL-Ghobashy. 1990. Some Ecological aspects of the western region of Manzala lagoon, Egypt. I-Physico-chemical characteristics. Mansoura Science Bulletin, 17: 166-184.

2. Abdel Ghaffer, E. 2006. Impact of climate change on the hydrology of Lake El Manzala. Paper presented at the First International Conference: Environmental Change in Lakes, Lagoons and Wetlands of the Southern Mediterranean Region, 4-7 January 2006, Cairo.

3. Ahmed, M. H., B. M. El-leithy, N. S. Donia and S. M. Arafat. 2006. Monitoring the historical changes of Lake Manzala ecosystems during the last three decades using multi dates satellite images, 1st Inter. Conf. on Envir. Change of Lakes, Lagoons and Wetlands of the Southern Mediterranean Region, 3-7 January, 06, Cairo, Egypt. ECOLLAW, 2006.

4. Bishai, H. M. and S. F. Yosef. 1977. Some aspects of the hydrography, physicochemical characteristics and fisheries of Manzala Lake. Bulletin of National Institute of Oceanography \& Fisheries, 7: 32-58.

5. Černa, L. and M. Chytry. 2005. Supervised classification of plant communities with artificial neural networks, Journal of Vegetation Science, vol. 16, no. 4, pp. 407-414.

6. Dewidar, KH. M. 2011. Monitoring temporal changes of the surface water area of the Burullus and Manzala lagoons using automatic techniques applied to a Landsat satellite data series of the Nile Delta coast. Medit. Mar. Sci., 12/2, 2011, 462-478.

7. Dinar, A., P. Seidl, H. Olem, V. Jorden, A. Duda and R. Johnson. 1995. Restoring and protecting the world's lakes and reservoirs. World Bank Publications. ISBN 08213-3321-6.

8. EGSA (Egyptian Geological Survey Authority) 1988. "Egyptian General Petroleum Corporation: Geological Map of Egypt", Conoco Coral, printed in Germany by Institute fur Angewandte Geodasie, Berlin, Technische Fachhochschule Berlin, Scale 1:500000.

9. Elmorsi, R. R., M. A. Hamed and K. S. Abou-El-Sherbini. 2017. Physicochemical Properties of Manzala Lake, Egypt, Egypt. J. Chem. Vol. 60, No. 4, pp. 519-535.

10. ERDAS 2014. ERDAS IMAGINE handbook - Features Next-Generation Spatial Modeler". Retrieved 2014-03-11.

11. ESRI 2016. Arc Map version 10.4.1 User Manual. ESRI, 380 New York Street, Redlands, California, 92373-8100, USA. 
12. Lambin, E. F., H. Geist and E. Lepers. 2003. Dynamics of land use and cover change in tropical regions. Annual Review of Environment and Resources 28: 205-241.

13. Lu, D., P. Mausel, E. Brondizio and E. Moran. 2004. Change detection techniques. Int J Remote Sens 25:2365-2404.

14. McFeeters, S.K. 1996. The use of the Normalized Difference Water Index (NDWI) in the delineation of open water features. International journal of remote sensing 17(7): 1425-1432. distance measure and spatial information", Remote Sensing, vol. 10 , no. 1 , pp. $133-146$.

15. Institute, Agricultural Research Center, Egypt.

16. Xu, H., 2006. Modification of normalized difference water index (NDWI) to enhance open water features in remotely sensed imagery. Int J Remote Sens 27:3025-3033. 
رصد بعض التغير ات في بحيرة المنزلة باستخدام

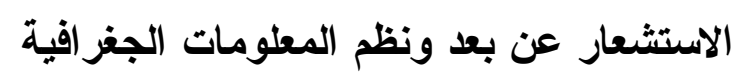

محمد محمد حسنى شومان

وحدة الاستشعار عن بعد ونظم الدعلومات الجغرافية -معهد بحوث الأراضي والمياه والبيئة - مركز البحوث الزراعية

تعتبر بحيرة المنزلة من أكبر البحيرات المتواجدة شمال دلتا جمهورية مصر العربية وتعتبر المصدر الأهم من مصادر الإنتاج السكي في مصر • وتتعرض البحيرة الى العديد من المؤثرات بسبب النشاط البشرى مثل عمليات التجفيف لبعض المناطق من البحيرة لتتحول الى مناطق زر اعية او حضرية وكذلك عمليات الاستقطاع لأجزاء كبيرة من البحيرة لأنشاء المزارع السمكية. لذلك لكأل تهدف هذه الدراسة الى رصد التغيرات الحادثة للبحيرة في فنرات زمنية متعددة باستخدام تحليل المرئيات الفضائية متعددة الازمنة من مستشعر ات LANDSAT-1 MSS و LANDSAT-5 TM و 4 و Sentinel-2A لأعو ام 1972 و1984 و 1991 و2006 و 2017 وباستخدام دليل التفرقة الطبيعي للماء NDWI ودليل التفرقة الطبيعي للماء المعدل MNDWI و التصنيف الموجة للمرئيات الفضائية. حيث تم رصد نتاقص في المسطح البحيرة حيث أظهرت النتائج تناقص المسطح المائي

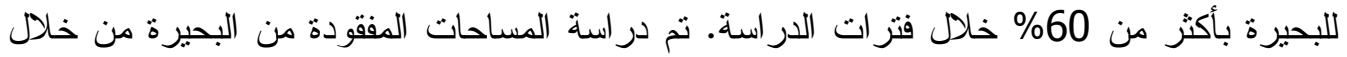
در اسة الغطاء الأرضي لهذه المساحات في الفترة من 1972 حتى 2017 باستخدام التصنيف الموجة للمرئيات الفضائية حيث تم تقسيم المساحات الى 4 اقسام تصنيفية رئيسية هي الأر اضي المنزر عة الهة (حو الى 75051 فدان) و الأر اضي البور (حو الى 13573 فدان) و المناطق الحضرية (حو الى 1338 ولى فدان) و الاحو اض السمكية (حو الى 83721 فدان). وبمقارنة المساحة المتأكلة من بحيرة المنزلة في

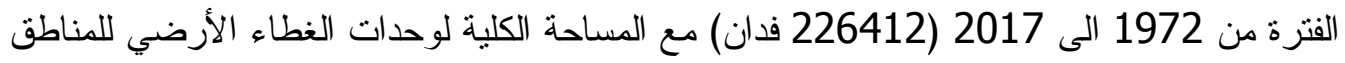
المستقطعة من البحيرة لنفس الفترة الزمنية (225783 فدان) وجد فرق في المساحة حوالى 629 فدان قد تأكلت وفقدت من البحيرة بفعل البحر المتوسط. 
